\title{
Bimbingan Penyesuaian Diri Berbasis Cerita Malangan di Sekolah Menengah Pertama
}

\author{
Sri Astutik ${ }^{1}$, M. Ramli ${ }^{1}$, Carolina L. Radjah ${ }^{1}$ \\ ${ }^{1}$ Bimbingan dan Konseling-Universitas Negeri Malang
}

\begin{tabular}{l} 
INFO ARTIKEL \\
\hline Riwayat Artikel: \\
Diterima: $02-01-2020$ \\
Disetujui: $15-10-2020$ \\
\hline
\end{tabular}

\section{Kata kunci:}

adjustment guidance;

poor story;

junior high school;

bimbingan penyesuaian diri,

cerita malangan;

sekolah menengah pertama

\begin{abstract}
ABSTRAK
Abstract: The purpose of this study is to describe the implementation of malanganbased story adjustment guidance in the Junior High School. The implementation of this malangan story-based self-adjustment guidance consists of: a) Phase I, namely the preimplementation of the BK Teacher preparing the group guidance RPL, b) Phase II of the process of carrying out the adjustment guidance activity includes (1) Initial stage, statement of purpose, group formation, consolidation, (2) Phase transition, experimentation, identification, analysis and termination, and (3) Phase III, reflection and follow-up. Thus, the researcher concludes that the implementation of the poor story-based self-adjustment guidance has been carried out properly in accordance with the steps of the self-adjustment guidance.
\end{abstract}

\begin{abstract}
Abstrak: Tujuan penelitian ini adalah untuk mendeskripsikan pelaksanaan bimbingan penyesuaian diri berbasis cerita malangan di Sekolah Menengah Pertama. Pelaksanaan bimbingan penyesuaian diri berbasis cerita malangan ini terdiri dari (a) Tahap I yaitu pra pelaksanaan Guru BK menyusun RPL bimbingan kelompok, (b) Tahap II proses pelaksanaan kegiatan bimbingan penyesuaian diri, meliputi (1) Tahap awal, pernyataan tujuan, pembentukan kelompok, konsolidasi dan (2) Tahap transisi, eksperientasi, identifikasi, analisis dan terminasi dan (c) Tahap III, refleksi dan tindak lanjut. Dengan demikian, peneliti menyimpulkan bahwa pelaksanaan bimbingan penyesuaian diri berbasis cerita malangan telah terlaksana dengan baik sesuai dengan langkah-langkah bimbingan penyesuaian diri.
\end{abstract}

\section{Alamat Korespondensi:}

Sri Astutik

Bimbingan dan Konseling

Universitas Negeri Malang

Jalan Semarang 5 Malang

E-mail: sastutik751@gmail.com

Bimbingan adalah upaya yang dilakukan oleh konselor secara sistematis, objektif, logis, dan berkelanjutan secara terprogram untuk memfasilitasi perkembangan konseli dalam mencapai kemandirian. Penyesuaian diri adalah kemampuan individu untuk mengubah diri sendiri sesuai dengan lingkungan, dilanjutkan dengan mengubah lingkungan sesuai dengan keadaan diri (Gerungan, 2010). Penyesuaian diri, meliputi kegiatan belajar untuk menghadapi keadaan baru melalui perubahan dalam sikap dan tingkah laku (Desmita, 2016). Penyesuaian diri berdasarkan pendapat dua ahli tersebut adalah kemampuan yang dimiliki oleh individu untuk memberikan respons mental dan tingkah laku terhadap lingkungan dan berusaha untuk mengatasi lingkungan yang mengancam, membahayakan keberadaan atau kesejahteraan dan kenyamanan diri seseorang, kemudian mengubah lingkungan sesuai dengan keadaan dirinya. Apabila individu dapat menyesuaikan diri dengan baik maka individu akan dapat mereaksi perubahan lingkungan secara dewasa, efisien dan memuaskan, sebaliknya jika individu tidak dapat menyesuaikan diri dengan baik maka individu akan mengalami ketidakefisienan dan ketidakpuasan dalam dirinya (Hastuti, 2008).

Tujuan bimbingan dan konseling yang berkaitan dengan aspek pribadi sosial konseli termuat dalam pedoman penataan pendidikan profesional (Dirjendikti, 2008) adalah (a) memiliki komitmen yang kuat dalam mengamalkan nilai-nilai keimanan dan ketaqwaan, (b) memiliki sikap toleransi terhadap umat beragama, (c) memiliki pemahaman tentang irama kehidupan yang kadang menyenangkan dan menyedihkan, (d) memiliki pemahaman dan penerimaan diri secara obyektif terkait dengan keunggulan dan kelemahan, (e) memiliki sikap positif atau respek terhadap diri dan orang lain, (f) memiliki respect terhadap orang lain, (g) memiliki kemampuan berinteraksi sosial, (h) memiliki kemampuan dalam menyelesaikan konflik, dan (i) memiliki kemampuan untuk mengambil keputusan secara efektif.

Cerita rakyat adalah ekspresi budaya masyarakat malang melalui bahasa tutur yang berhubungan langsung dengan berbagai aspek budaya dan susunan nilai sosial masyarakat (Hutomo, 1991). Sisyono, dkk (2008) menyatakan bahwa cerita rakyat merupakan salah satu jenis karya sastra yang berupa cerita yang lahir hidup dan berkembang pada beberapa generasi dalam masyarakat tradisional, baik masyarakat itu telah mengenal huruf atau belum, disebarkan secara lisan, mengandung 
survival, bersifat anonim serta disebarkan diantara kolektif tertentu dalam kurun waktu yang cukup lama. Dari dua pendapat tersebut dapat disimpulkan bahwa cerita rakyat malangan adalah cerita yang dituturkan secara lisan yang memuat nilai budaya dan tatanan nilai sosial serta aspek budi pekerti dan moral yang berkembang di masyarakat, dalam hal ini adalah masyarakat Malang. Cerita malangan yang dimaksud dalam hal ini adalah (1) cerita gunung arjuno dan (2) cerita roro anteng dan joko seger.

Cerita gunung arjuno dipilih karena memuat nilai-nilai sifat kerendahan hati untuk mengakui kesalahan dan berterima kasih serta menerima nasihat yang diberikan oleh orang lain. Dua nilai yang terkandung dalam cerita gunung arjuno dapat dijadikan sebagai media untuk memberikan bimbingan penyesuaian diri bagi siswa SMP (Hastuti, 2008). Sementara itu, cerita roro anteng dan joko seger memuat nilai-nilai pengembangan sikap taat dan patuh terhadap orangtua, menepati janji, tanggung jawab, ikhlas, dan kasih sayang. Keempat nilai yang terkandung di dalam cerita roro anteng dan joko seger dapat dijadikan sebagai media dalam menyampaikan bimbingan penyesuaian diri terhadap siswa.

Batasan masalah dalam penelitian ini adalah tentang deskripsi pelaksanaan bimbingan penyesuaian diri berbasis cerita malangan di SMP Negeri 11 Malang. Rumusan masalah dalam penelitian ini adalah, Bagaimanakah deskripsi pelaksanaan bimbingan penyesuaian diri berbasis cerita malangan di SMP Negeri 11 Malang? Tujuan penelitian ini adalah untuk mengetahui deskripsi pelaksanaan bimbingan penyesuaian diri berbasis cerita malangan di SMP Negeri 11 Malang. Manfaat penelitian ini secara umum adalah guru BK dapat melaksanakan bimbingan penyesuaian diri berbasis cerita malangan sesuai dengan langkahlangkah yang baku.

Bimbingan penyesuaian diri adalah usaha yang dilakukan oleh guru bimbingan dan konseling untuk membantu siswa dalam mengembangkan kemampuan siswa dalam memberikan respons terhadap tuntutan yang ada dalam diri dan lingkungannya secara tepat sehingga siswa memperoleh kebahagiaan dan kesuksesan dalam kehidupannya (Hidayah, Pali, Ramli, Hanurawan, 2016). Bimbingan penyesuaian diri sebagai bagian dari layanan dasar sangat penting diberikan kepada siswa SMP dikarenakan fungsi bimbingan penyesuaian diri adalah untuk membantu mengembangkan kemampuan siswa secara optimal (Suryani, Syahniar, Zikra, 2013). Peneliti menemukan fakta di lapangan, pelaksanaan bimbingan penyesuaian diri belum optimal setelah melakukan wawancara dengan guru BK di salah satu sekolah Negeri di Malang. Identifikasi masalah dalam penelitian ini adalah (1) pelaksanaan bimbingan penyesuaian diri terhadap siswa dilaksanakan secara incidental dikarenakan guru BK tidak memiliki jam khusus di kelas; (2) ditemukan beberapa siswa yangt memiliki penyesuaian diri yang kurang. Berdasarkan hasil identifikasi masalah dan analisis kebutuhan tersebut maka penelitian ini bertujuan untuk mendeskripsikan pelaksanaan bimbingan penyesuaian diri berbasis cerita malangan di Sekolah menengah Pertama.

\section{METODE}

Penelitian ini menggunakan metode deskriptif kualitatif yaitu penelitian yang menjelaskan tentang keadaan yang sebenarnya di lapangan (Sugiono, 2018). Tujuan dalam penelitian deskriptif kualitatif ini adalah untuk mendeskripsikan pelaksanaan bimbingan penyesuaian diri berbasis cerita malangan di SMP Negeri 11 Malang. Subjek penelitian adalah siswa kelas VII-G dan tempat penelitian di SMP Negeri 11 Malang. Waktu penelitian pada bulan November tahun 2019. Populasi dalam penelitian ini adalah siswa kelas VII-G SMP Negeri 11 Malang sebanyak 32 orang siswa. Teknik pengambilan sampel adalah random sampling yaitu mengambil sample secara acak tanpa memperhatikan strata dalam populasi (Sugiono, 2017). Teknik pengumpulan data dalam penelitian ini adalah menggunakan lembar evaluasi dan lembar refleksi bimbingan penyesuaian diri. Kisi-kisi yang digunakan dalam penyusunan lembar evaluasi dan lembar refleksi dalam penelitian ini disajikan pada tabel 1, 2, dan 3 .

Menurut (Sugiyono, 2018) analisis deskriptif adalah proses mencari dan menyusun secara sistematis data yang diperoleh dari hasil wawancara, catatan di lapangan, dan dokumentasi. Jenis data yang dikumpulkan dalam penelitian ini adalah hasil lembar evaluasi dan lembar refleksi yang dinyatakan dalam bentuk pendapat dan dianalisis dengan analisis deskriptif kualitatif. Langkah-langkah analisis yang dilakukan dalam penelitian ini, meliputi (1) mengelompokkan aspek yang diamati melalui pelaksanaan bimbingan penyesuaian diri berbasis cerita malangan yang direncanakan, mengamati kemampuan guru BK dalam melaksanakan bimbingan penyesuaian diri dan hasil lembar evaluasi dan lembar refleksi setelah kegiatan bimbingan penyesuaian diri, (2) menganalisis terlaksana atau tidaknya setiap aspek yang diamati, dan (3) mendeskripsikan pelaksanaan bimbingan penyesuaian diri berbasis cerita malangan. 
Tabel 1. Kisi-Kisi Lembar Evaluasi Bimbingan Penyesuaian Diri Berbasis Cerita Malangan

\begin{tabular}{|c|c|c|c|}
\hline Cerita Malangan & Indikator & Nomor Butir & Jumlah \\
\hline \multirow{4}{*}{ Cerita Gunung Arjuno } & $\begin{array}{l}\text { Kemampuan untuk mengungkapkan permasalahan penyesuaian diri yang terjadi } \\
\text { pada siswa. }\end{array}$ & 1 & \multirow{4}{*}{4} \\
\hline & $\begin{array}{l}\text { Kemampuan siswa dalam merekonstruksi yaitu menghubungkan permasalahan } \\
\text { penyesuaian diri yang dihadapi dengan permasalahan yang terkandung dalam } \\
\text { cerita gunung arjuno. }\end{array}$ & 2 & \\
\hline & $\begin{array}{l}\text { Kemampuan siswa dalam mengungkapkan perasaan setelah berhasil menemukan } \\
\text { solusi dari permasalahan penyesuaian diri yang kalian hadapi melalui cerita } \\
\text { gunung arjuno. }\end{array}$ & 3 & \\
\hline & Mengungkapkan kesan setelah melakukan kegiatan ini. & 4 & \\
\hline \multirow{4}{*}{$\begin{array}{l}\text { Cerita Roro Anteng dan } \\
\text { Joko Seger }\end{array}$} & $\begin{array}{l}\text { Kemampuan untuk mengungkapkan permasalahan penyesuaian diri yang terjadi } \\
\text { pada siswa. }\end{array}$ & 1 & \multirow{4}{*}{4} \\
\hline & $\begin{array}{l}\text { Kemampuan siswa dalam merekonstruksi yaitu menghubungkan permasalahan } \\
\text { penyesuaian diri yang dihadapi dengan permasalahan yang terkandung dalam } \\
\text { cerita roro anteng dan joko seger. }\end{array}$ & 2 & \\
\hline & $\begin{array}{l}\text { Kemampuan siswa dalam mengungkapkan perasaan setelah berhasil menemukan } \\
\text { solusi dari permasalahan penyesuaian diri yang kalian hadapi melalui cerita roro } \\
\text { anteng dan joko seger. }\end{array}$ & 3 & \\
\hline & Mengungkapkan kesan setelah melakukan kegiatan ini. & 4 & \\
\hline
\end{tabular}

Tabel 2. Kisi-Kisi Lembar Refleksi Bimbingan Penyesuaian Diri Berbasis Cerita Malangan

\begin{tabular}{clc}
\hline Cerita Malangan & \multicolumn{1}{c}{ Indikator } \\
\hline Cerita Gunung Arjuno & $\begin{array}{l}\text { Pengalaman perasaan siswa setelah mengungkapkan permasalahan peyesuaian } \\
\text { diri yang sedang dialami }\end{array}$ \\
& $\begin{array}{c}\text { Pengalaman siswa setelah berdiskusi tentang isi cerita gunung arjuno. } \\
\text { Kemampuan siswa dalam menemukan keterkaitan antara permasalahan } \\
\text { penyesuaian diri yang sedang dialami dengan cerita gunung arjuno. }\end{array}$ \\
Cerita Roro Anteng dan & $\begin{array}{l}\text { Pengalaman perasaan siswa setelah mengungkapkan permasalahan peyesuaian } \\
\text { diri yang sedang dialami }\end{array}$ \\
& $\begin{array}{l}\text { Pengalaman siswa setelah berdiskusi tentang isi cerita roro anteng dan joko } \\
\text { seger. }\end{array}$ \\
& $\begin{array}{l}\text { Kemampuan siswa dalam menemukan keterkaitan antara permasalahan } \\
\text { penyesuaian diri yang sedang dialami dengan cerita roro anteng dan joko seger. }\end{array}$ \\
& 3 \\
\hline
\end{tabular}

Tabel 3. Kisi-Kisi Evaluasi Bimbingan Penyesuaian Diri Berbasis Cerita Malangan

\begin{tabular}{|c|c|c|c|}
\hline Variabel & Indikator & No Butir & Jumlah \\
\hline \multirow[t]{10}{*}{ Bimbingan Penyesuaian Diri } & Materi bimbingan sesuai dengan kebutuhan & 1 & \multirow{10}{*}{15} \\
\hline & Siswa terlibat aktif dalam kegiatan bimbingan & $2,5,6$ & \\
\hline & Guru BK menggunakan media yang menarik & 3 & \\
\hline & Guru BK merespon pertanyaan/cerita dengan penghargaan yang baik & 7 & \\
\hline & Siswa dapat melakukan identifikasi & 8 & \\
\hline & Siswa dapat melakukan analisis & 9 & \\
\hline & Siswa dapat melakukan generalisasi & 10 & \\
\hline & Siswa mendapat keterampilan baru & $11,12,13$ & \\
\hline & Siswa dapat mengatasi masalah & 14 & \\
\hline & Siswa merekomendasi teman untuk mengikuti kegiatanh bimbingan & 15 & \\
\hline
\end{tabular}




\section{HASIL}

Pelaksanaan bimbingan penyesuaian diri berbasis cerita malangan, meliputi tiga tahapan, yaitu (a) tahap I, pra pelaksanaan Guru BK menyusun RPL bimbingan kelompok; (b) tahap II, proses pelaksanaan kegiatan bimbingan penyesuaian diri, meliputi (1) tahap awal, pernyataan tujuan, pembentukan kelompok, konsolidasi dan (2) tahap transisi, eksperientasi, identifikasi, analisis, dan terminasi; (c) tahap III, refleksi dan tindak lanjut.

Pendeskripsian hasil penelitian secara kualitatif dalam penelitian ini disajikan dalam bentuk menyusun data secara sistematis yang diperoleh dari hasil pengisian lembar evaluasi dan lembar refleksi. Pendeskripsian hasil penelitian secara kuantitatif disajikan dalam bentuk analisis deskriptif. Selanjutnya, data kualitatif hasil evaluasi dapat disajikan sebagai berikut. Pertama, semua siswa tidak mengalami kesulitan dalam mengungkapkan permasalahan yang terjadi pada diri sendiri baik pada sesi cerita gunung arjuno maupun cerita roro anteng dan joko seger. Kedua, semua siswa tidak mengalami kesulitan dalam melakukan rekonstruksi dalam menghubungkan permasalahan penyesuaian diri yang dihadapi dengan permasalahan yang terkandung dalam cerita gunung arjuno maupun cerita roro anteng dan gunung seger. Ketiga, semua siswa merasa senang dan lega setelah menemukan solusi dari permasalahan penyesuaian diri yang dihadapi melalui cerita gunung arjuno maupun cerita roro anteng dan joko seger. Keempat, siswa memiliki kesan antara lain, dibiasakan untuk membaca, merasa senang, dapat menerapkan dalam kehidupan sehari-hari setelah mengikuti kegiatan bimbingan penyesuaian diri berbasis cerita malangan ini.

Data kualitatif hasil refleksi disajikan sebagai berikut. Pertama, siswa merasa senang dan lega karena dapat mengungkapkan permasalahan penyesuaian diri yang sedang dialami kepada teman. Kedua, pengalaman siswa setelah melakukan diskusi tentang isis cerita gunung arjuno dan joko seger dan roro anteng antara lain: mendapatkan amanat, ilmu, kesan dan nilai-nilai yang baik dan dapat diterapkan dalam kehidupan sehari-hari, mendapatkan pesan moral yang baik, mendapatkan pengetahuan, pengalaman baru, dan pembelajaran yang dapat diterapkan dalam kehidupan sehari-hari. Ketiga, keterkaitan antara permasalahan penyesuaian diri yang dialami siswa dengan cerita gunung arjuno dan roro anteng dan joko seger yaitu melalui cerita ini kita mendapatkan solusi dari permasalahan dan dapat diterapkan dalam kehidupan sehari-hari, melalui cerita ini menjadi lebih mengerti, lebih tahu, mendapatkan solusi, menjadi patuh kepada orangtua, mendapatkan motivasi, pelajaran yang nyaman, dan dapat diterapkan dalam kehidupan sehari-hari.

Tabel 4. Hasil Evaluasi Guru Kegiatan Bimbingan Penyesuaian Diri Berbasis Cerita Malangan

\begin{tabular}{|c|c|c|c|}
\hline No & Aspek yang dievaluasi & Sesi 1 & Sesi 2 \\
\hline 1. & Materi yang disampaikan dalam bimbingan penyesuaian diri dibutuhkan oleh siswa & 3 & 3 \\
\hline 2. & Siswa terlibat aktif & 3 & 4 \\
\hline 3. & Guru BK menggunakan media yang menarik & 3 & 4 \\
\hline 4. & Siswa senang mengikuti kegiatan bimbingan kelompok pada pertemuan ini & 3 & 4 \\
\hline 5. & Kegiatan bimbingan penyesuaian diri memberikan manfaat bagi siswa & 3 & 3 \\
\hline 6. & Siswa merasa nyaman dalam kelompok & 3 & 4 \\
\hline 7. & Guru BK merespon pertanyaan/cerita dengan penuh penghargaan & 3 & 4 \\
\hline 8. & Siswa dapat mengambil pelajaran dari pengalaman yang didapatkan dari bimbingan penyesuaian diri & 3 & 3 \\
\hline 9. & Siswa dapat menggunakan pelajaran yang didapat dalam kehidupan & 3 & 3 \\
\hline 10. & Siswa dapat merancang masa depan untuk mengoptimalkan kehidupannya & 3 & 3 \\
\hline 11. & Kegiatan bimbingan penyesuaian diri membuat siswa memiliki pengetahuan baru & 3 & 4 \\
\hline 12. & Kegiatan bimbingan penyesuaian diri membuat siswa memiliki keterampilan baru & 3 & 3 \\
\hline 13. & Kegiatan bimbingan penyesuaian diri membuat siswa memiliki empati terhadap sesama anggota & 3 & 4 \\
\hline 14. & Kegiatan bimbingan penyesuaian diri dapat membantu siswa dalam mengatasi masalah & 3 & 4 \\
\hline \multirow[t]{3}{*}{15.} & Siswa akan merekomendasikan teman untuk mengikuti kegiatan bimbingan peneysuaian diri ini & 3 & 3 \\
\hline & Jumlah skor & 45 & 53 \\
\hline & Rerata skor pertemuan I dan II & 3 & 3,5 \\
\hline
\end{tabular}

\section{PEMBAHASAN}

Pelaksanaan bimbingan penyesuaian diri berbasis cerita malangan meliputi tiga tahapan, yakni (a) tahap I yaitu pra pelaksanaan Guru BK menyusun RPL bimbingan kelompok, (b) Tahap II proses pelaksanaan kegiatan bimbingan penyesuaian diri, dan (c) tahap III, refleksi dan tindak lanjut. Tahap II proses pelaksanaan kegiatan bimbingan penyesuaian diri, meliputi (1) tahap awal, pernyataan tujuan, pembentukan kelompok, konsolidasi dan (2) tahap transisi, eksperientasi, identifikasi, analisis, dan terminasi.

Tahap I pra pelaksanaan bimbingan guru BK menyiapkan Rencana Pelaksanaan Layanan (RPL) Bimbingan Kelompok. Tahap ini merupakan langkah yang penting bagi guru BK karena di dalam RPL bimbingan kelompok memuat Identitas layanan, bidang bimbingan, jenis bimbingan, standard kompetensi, waktu, tujuan, kompetensi dasar, indikator, materi, metode/teknik, alat dan bahan, kelas, semester. Sistematika RPL bimbingan kelompok ini sesuai dengan panduan operasional yang telah ditetapkan oleh pemerintan (Kemendikbud, 2016). Standar kompetensi yang digunakan disesuaikan dengan perkembangan siswa (Hurlock, 2017). 
Tahap II kegiatan bimbingan penyesuaian diri dimulai dengan pernyataan tujuan pelaksanaan bimbingan dilanjutkan dengan pembentukan kelompok dan konsolidasi. Kelompok dibagi menjadi dua yaitu kelompok gunung arjuno dan kelompok roro anteng dan joko seger. Setelah terbentuk kelompok kegiatan selanjutnya adalah masing-masing kelompok melakukan konsolidasi untuk persiapan kegiatan tahap berikutnya. Setelah masing-masing melakukan konsolidasi, guru BK menyampaikan kepada anggota kelompok tentang kegiatan selanjutnya yaitu membaca cerita malangan sambil memperhatikan tayangan narasi cerita lewat PPT yang ditayangkan oleh guru BK. Setelah selesai siswa diminta untuk mengungkapkan permasalahan penyesuaian diri yang dialami kepada teman, kemudian mengidentifikasi masalah penyesuaian diri yang dialami dan menganalisis. Kegiatan analisis ini dilakukan dengan cara meminta anggota kelompok untuk berdiskusi dalam kelompok tentang penyebab masalah penyesuaian diri yang dialami dan solusi yang dapat diberikan melalui pada cerita malangan yang dibaca sebelumnya dilanjutkan dengan terminasi atau pengakhiran kegiatan.

Tahap III adalah refleksi dan tindak lanjut. Dalam kegiatan ini semua anggota kelompok diminta untuk mengisi lembar evaluasi dan refleksi yang dibagikan oleh guru BK. Semua siswa mengisi lembar evaluasi dan refleksi secara bersamaan. Beragam hasil evaluasi siswa menunjukkan (1) siswa tidak mengalami kesulitan dalam mengungkapkan permasalahan penyesuaian diri, (2) siswa tidak mengalami kesulitan dalam merekonstruksi dalam menghubungkan permasalahan penyesuaian diri yang dihadapi dengan permasalahan yang terkandung dalam cerita gunung arjuna/roro anteng dan joko seger, (3) siswa merasa senang dan lega setelah menemukan solusi dari permasalahan penyesuaian diri yang dihadapi melalui cerita gunung arjuna/roro anteng dan joko seger, dan (4) siswa memiliki kesan untuk membiasakan diri membaca, merasa senang dengan kegiatan ini dan dapat menerapkan dalam kehidupan sehari-hari. Hasil refleksi kegiatan bimbingan penyesuaian diri berbasis cerita malangan, meliputi (1) siswa memiliki pengalaman dalam mengungkapkan permasalahan kepada teman dan merasa merasa senang dan lega sudah bisa cerita kepada teman masalah penyesuaian diri, (2) pengalaman siswa setelah berdiskusi tentang isi cerita gunung arjuno/roro anteng dan joko seger yaitu mendapatkan pesan moral yang baik, mendapatkan pengetahuan, pengalaman baru, dan pembelajaran yang dapat diterapkan dalam kehidupan sehari-hari, dan (3) keterkaitan cerita gunung arjuno/cerita roro anteng dan joko seger dengan masalah penyesuaian diri yaitu melalui cerita ini menjadi lebih mengerti, lebih tahu, mendapatkan solusi, menjadi patuh kepada orang tua, mendapatkan motivasi, mendapatkan pelajaran yang nyaman dan dapat diterapkan dalam kehidupan sehari-hari. Hasil evaluasi guru terhadap pelaksanaan bimbingan penyesuaian diri pada sesi I dan II. Pada sesi I, jumlah skor yang diperoleh adalah 45 dengan kategori sangat sesuai. Sementara itu, rata-rata skor adalah 3 dengan kategori sesuai. Selanjutnya, dapat disimpulkan bahwa pelaksanaan bimbingan penyesuaian diri berbasis cerita malangan sudah dilaksanakan dengan baik sesuai dengan langkah-langkah bimbingan. Pada sesi II, jumlah skor yang diperoleh adalah 53 dengan kategori sangat sesuai. Sementara itu, rata-rata skor adalah 3,5 kategori sesuai. Dapat disimpulkan bahwa pelaksanaan bimbingan penyesuaian diri dapat terlaksana dengan baik sesuai dengan langkah-langkah bimbingan. Dengan demikian, peneliti menyimpulkan pelaksanaan bimbingan penyesuaian diri berbasis cerita malangan di SMP Negeri 11 Malang telah terlaksana dengan baik sesuai dengan langkah-langkah bimbingan penyesuaian diri.

\section{SIMPULAN}

Pelaksanaan kegiatan bimbingan penyesuaian diri berbasis cerita malangan telah terlaksana dengan sangat baik dan sesuai dengan langkah-langkah bimbingan. Langkah-langkah bimbingan penyesuaian diri, meliputi (1) tahap I pra pelaksanaan bimbingan, (2) tahap II pelaksanaan bimbingan penyesuaian diri, dan (3) tahap III penutup. Berdasarkan hasil penelitian mengenai deskripsi pelaksanaan bimbingan penyesuaian diri berbasis cerita malangan untuk siswa Sekolah Menengah Pertama , maka saran yang diusulkan, yaitu (1) untuk guru BK hendaknya guru BK melaksanakan bimbingan penyesuaian diri berbasis cerita malangan sesuai dengan langkah-langkah bimbingan dan (2) untuk peneliti berikutnya hendaknya melakukan uji efektivitas terhadap langkah-langkah bimbingan penyesuaian diri dengan dengan populasi yang lebih luas.

\section{DAFTAR RUJUKAN}

Aridhona, J. (2017). Hubungan Antara Kecerdasan Spiritual dan Kematangan Emosi dengan Penyesuaian Diri pada Remaja. Psiko Islamedia Jurnal Psikologi, 2(2), 131-145.

Desmita. (2016). Psikologi Perkembangan Peserta Didik. Bandung: PT. Remaja.

Diretorat Jenderal Pendidikan Tinggi. (2008). Penataan Pendidikan Profesional Konselor dan Layanan Bimbingan dan Konseling dalam Jalur Pendidikan Formal. Jakarta: Depdiknas

Fitri, L. N. (2017). Pengaruh Penyesuaian Diri dan Penyesuaian Sosial terhadap Prestasi Akademik Siswa. Jurnal Riset Mahasiswa Bimbingan dan Konseling, 3(8), 457-464.

Gerungan. (2010). Psikologi Sosial. Bandung: PT. Refika Aditama.

Hastuti, W. (2008). Penyesuaian Diri. Jurnal (Profesional) Media Publikasi Penelitian, 3, 66-70.

Hayuni, R. R., \& Flurentin, E. (2016). Pengembangan Panduan Sosiodrama untuk meningkatkan Kepedulian Siswa SMP. Jurnal Kajian Bimbingan dan Konseling (JKBK), 1(3), 118-125.

Hidayah, N, Pali, M. Ramli, M., \& Hanurawan, F. (2016). Students Well-Being Assesment at School. Journal of Educational Health and Community Psychology, 5(1), 62-71.

Hidayat, M. Y. (2008). Implikasi Bibliokonseling sebagai Salah Satu Strategi Membantu Klien dalam Konseling. Lentera Pendidikan: Jurnal Tarbiyah dan Keguruan, 11(1), 129-140. 
Husiselan, N. (2016). Efektivitas Bimbingan Kelompok untuk Meningkatkan Penyesuaian Diri Mahasiswa Program Studi Bimbingan dan Konseling Universitas Pattimura Ambon. Jurnal Psikologi dan Konseling, 8(1), 1-12.

Hurlock, E. B. (2017). Psikologi Perkembangan:Suatu Pendekatan Sepanjang Rentang Kehidupan (Edisi Kelima). Jakarta: Erlangga.

Hutomo, S. S. (1991). Mutiara yang Terlupakan: Pengantar Studi Sastra Lisan. Himpunan Sarjana Kesusastraan Indonesia. Jawa Timur, Komisariat HSKII.

Kemendikbud. (2016). Panduan Operasional Bimbingan dan Konseling. Jakarta: Depdikbud.

Khairiyah., Wati, M., \& Hartini, S. (2015). Hubungan Kepercayaan Diri dengan Hasil belajar Siswa Kelas VIII MTSn Mulawarman Banjarmasin pada Mata Pelajaran IPA. Jurnal Berkala Ilmiah Pendidikan Fisika, 3(3), 200 -210.

Lidya, S. F., \& Darmayanti, N. (2015). Self Efficacy Akademik dan Penyesuaian Diri Siswa kelas X SMA Patra Nusa. Jurnal Diversita, 1(1), 43-54.

Manik, R., Radjah, C. L., \& Triyono. (2017). Rendahnya Konsep Diri Akademik Siswa SMP. Jurnal Pendidikan: Teori, Penelitian, dan Pengembangan, 2(4), 494-502.

Mubarok, A. F. (2012). Penyesuaian Diri Para Pendatang di Lingkungan Baru. Journal of Social and Industrial Psychology, $1(1), 21-27$.

Mustofa, A. (2009). Mengapa Anak Bungkam Atas Pengealaman Kekerasan Seksual? Syndrom Penyesuaian Diri Roland Summit: Implementasi di Indonesia. Buletin Psikologi, 17(6), 39— 47.

Nuryono, W. (2012). Keefektifan Konseling Naratif untuk Meningkatkan Penerimaan Diri Siswa. Jurnal Psikologi Pendidikan dan Bimbingan, 13(1), 108-117.

Partha, I. D. P. (2018). Kontribusi Kemampuan Penyesuaian Diri dan Keterampilan Berkomunikasi terhadap Kemampuan Memecahkan Masalah pada Siswa SMA NW Tebaban. Jurnal Konseling Pendidikan, 2(2), 9-30.

Putri, S.A.P., \& Ramli, M. (2016). Penegmbangan Media Permaianan Simulasi Ular Tangga untuk Meningkatkan tanggung Jawab Siswa. Jurnal Kajian Bimbingan dan Konseling, 1(1), 40-46.

Radjah, C. L. (2016). Keterampilan Konseling Berbasis Metakognisi. Jurnal Kajian Bimbingan dan Konseling (JKBK), 1(3), $90-94$.

Sucipto. (2016). Konseling Kelompok dengan Media Animasi untuk Meningkatkan Penyesuaian Diri Siswa Sekolah Dasar. Jurnal Konseling Gusjigang, 2(2)133-138.

Sugiyono. (2018). Metode Penelitian Pendidikan: Pendekatan Kuantitatif, Kualitatif dan R \& D. Bandung: Alfabeta.

Suryani, L., Syahniar., \& Zikra. (2013). Penyesuaian Diri pada Masa Pubertas. Jurnal Ilmiah Konseling, 2(1), 136 - 140.

Syahrul, M. (2015). Pengaruh Layanan Bimbingan Kelompok terhadap Peningkatan Penyesuaian Diri Anak. Jurnal of EST, $1(1), 46-60$.

Windawati. (2015). Meningkatkan Kemampuan Penyesuaian Diri Siswa Melalui Teknik Cognitive Restructuring pada Kelas TKR 1 SMK Negeri 1 Semarang. Jurnal Penelitian Pendidikan, 2(1), $1-9$.

Zakiyah, N., Hidayati, F. N. R., \& Setyawan, I. (2010). Hubungan Antara Penyesuaian Diri dengan Prokrastinasi Akademik Siswa Sekolah Berasrama SMP N3 Peterongan Jombang. Jurnal Psokologi Undip, 2(2), 156-167. 